\title{
Measurement of Noise Pollution in Northern Industrial Areas of Windhoek, Namibia
}

\author{
Sylvanus Ameh Onjefu1', Emmanuel Ejembi1 ${ }^{*}$, Leonard Agbo Onjefu² \\ ${ }^{1}$ Department of Natural and Applied Sciences, Namibia University of Science and Technology, Windhoek, Namibia \\ ${ }^{2}$ Department of Civil and Environmental Engineering, Namibia University of Science and Technology, Windhoek, Namibia \\ Email: *eejembi@nust.na
}

How to cite this paper: Onjefu, S.A., Ejembi, E. and Onjefu, L.A. (2019) Measurement of Noise Pollution in Northern Industrial Areas of Windhoek, Namibia. Journal of Environmental Protection, 10, 1144-1154. https://doi.org/10.4236/jep.2019.109068

Received: July 13, 2019

Accepted: September 9, 2019

Published: September 12, 2019

Copyright () 2019 by author(s) and Scientific Research Publishing Inc. This work is licensed under the Creative Commons Attribution International License (CC BY 4.0).

http://creativecommons.org/licenses/by/4.0/

cc) (7) Open Access

\begin{abstract}
The increase in industrial activities and vehicular movement along the northern industrial area of Windhoek has vastly increased the amount of traffic noise and other noise pollution in the area. Noise pollution has an adverse health effect to human population, when exposed for a long period. Residence in proximate communities along the north industrial area and those working in the various industries located in the area may be affected, when the noise pollution level exceed the permissible standard for human exposure. A sound level meter was used to measure the amount of noise pollution at the streets of the northern industrial area. The measurements were done during the daytime, at a time interval of 2 hours, from 08:00 am - 06:00 pm. The amount of noise pollution obtained from the study ranges from $(64-72) \mathrm{dB}(\mathrm{A})$, with a maximum of $72 \mathrm{~dB}(\mathrm{~A})$ in Bonsmara Street, $(67.4$ - 75.3) $\mathrm{dB}(\mathrm{A})$, with a maximum of $75.3 \mathrm{~dB}(\mathrm{~A})$ in New Castle Street, $(60.5$ - 81.0) $\mathrm{dB}(\mathrm{A})$, with a maximum of $72.3 \mathrm{~dB}(\mathrm{~A})$ in Braham Street. $(62.5$ - 72.3) dB (A), with a maximum of $82.3 \mathrm{~dB}(\mathrm{~A})$ in Hosea Kutako Street, $(66.0-82.3) \mathrm{dB}(\mathrm{A})$, with a maximum of $76.8 \mathrm{~dB}(\mathrm{~A})$ in Simmentaler Street and $(65.1-76.8) \mathrm{dB}(\mathrm{A})$, with a maximum of $76.8 \mathrm{~dB}(\mathrm{~A})$ in Dortmund Street. The variation of noise level index $\mathrm{L}_{10}, \mathrm{~L}_{50}, \mathrm{~L}_{90}$ and $\mathrm{L}_{\text {eq }}$, Noise Climate (NC) and Traffic Noise index (TNI) were calculated. The maximum noise pollution values obtained from the study were higher than the WHO recommended limit of $70 \mathrm{~dB}(\mathrm{~A})$.
\end{abstract}

\section{Keywords}

Noise Pollution, Northern Industries, Sound Intensity, Source of Noise

\section{Introduction}

Noise pollution is one of the major sources of environmental pollution that can adversely affect the health system of human population. The source of most ur- 
ban noise pollution is mainly caused by human activities, such as the routine use of maintenance equipment, machines and transportation systems, motor vehicles, aircraft, and train [1]. Most of these human activities are carried out around the north industrial area of Windhoek. Noise pollutions are those unwanted, uncontrollable and unpredictable sound that produces a displeasing effect, which interferes with human communication, comfort and health [2]. Industrial areas are been known to contribute to these unpredictable sound levels. Noise pollution results when the loudness of the sound becomes irritating or unbearable. The northern industrial area of Windhoek Namibia is congested with several industrial activities. These activities sometimes generate severe noise to the environment to levels which can pose threat to human health. Some observed sources of noise pollution in the study areas include activities such as the movement of goods, vehicles, the operation of industrial machines, cutting and placement of metal rod and wood, uploading and transferring of heavy goods from vehicle, building construction and human activities. Noise pollution in the north industrial of Windhoek may pose an accumulative health effect, not only to industrial workers but also to costumers and human population living around the area. Exposure to excessive industrial noise can lead to sleep disorder, stress, distraction, loss of hearing, headache, high blood pressure, discomfort and can as well cause cardiovascular effect [3].

Continuous exposure to repeating noise to resident or workers around the northern industries, can lead to Psychological and physiological effects [4] [5]. The psychological effect caused by noise on people differs based on the situation of the person and the time spent by the person in that particular area. For example, people working in companies situated in the northern industrial area, in Windhoek, are more likely to be exposed to repeating sound from their own company or other company situated in that area.

Madbuli et al. [6] studied the noise pollution in metalwork and woodwork industries in the kingdom of Saudi Arabia; in their research, it was stated that Noise level varied according to the type and size of factory, and the type and number of machines used. According to their research, the mean noise level in metalwork is higher than that of woodwork. Therefore, people working or living close to the metalwork industry, at the north industrial area of Windhoek, may have high exposure to noise pollution than those in the woodwork industries. The effect of noise pollution on human population around the industrial area can also be determined by the amount of road traffic and other activities engaged by the local population in the area.

The movement of heavy vehicle, truck and goods vehicle in and out of industrial area, contribute to the amount of traffic noise release to the environment. The effect of noise pollution in cities around the world has been well documented [7] [8]. Studies have shown that exposure to environment traffic noise can leads to hypertension and preeclampsia in pregnant women [9]. As city populations continue to increase, vehicular traffic is becoming alarming, due to the increase in traffic congestion, in our road and industrial area [10]. Residents 
living along the streets close to traffic congestion area may be affected by traffic noise, especially during early hours of the day. Noise pollutant emanating from road traffic and industry has adverse effect on productivity. Industrial workers may have low productivity from noise distraction, learning process of students in high school located close to road traffic and the industrial area may be affected as well [11] [12] [13]. There are residents living along the streets that lead to the north industrial area of Windhoek. Also present are schools, offices and hospitals that are situated in proximate distance to the industrial area. Vehicles and heavy industrial trucks entering and leaving the area create traffic noise to residents, patients and school learners. This study will be relevant to the general public and policymakers in that it will help to create awareness of the levels of noise generated from the north industrial area which will form a baseline for future environmental noise assessment.

\section{Material and Method}

\subsection{Study Area}

Windhoek is the capital city of the republic of Namibia. The city is located at the central part of Namibia; the location is within the Khomas Highland plateau area. It has a distance of 1700 meters (5600 ft) above sea level, almost exactly at the country's geographical centre. The human population in Windhoek, is about 325, 858 according to 2011 census figure. However, the number continues to grow due to high influx of people from all over Namibia. The city has an annual average high and low temperature range to be $13.6 \mathrm{OC}(24.5 \mathrm{OF})$ with over 300 sunny days per year. The coldest month is July, while the hottest month is December. The City has an average precipitation of 367.4 millimeters, which is abundant during summer season and minimal during winter season. Windhoek is divided into four geographical locations, known as the northern, southern, western and eastern region. The Southern side is not suitable for industrial development because of its underground aquifers. This leaves the vast areas of the north of town as the only feasible place for Windhoek's expansion [14]. The northern region of Windhoek is where the industrial activities do take place hence, the location of industrial establishment. The northern industrial area of Windhoek comprises of the Bonsmara, Newcastle, Dortmud, Hosea kutako drive and Brahman Street. Figure 1 below is the map of the Northern industrial area, showing their respective street, in which the study was conducted.

\subsection{Source of Noise}

The sources of noise include vehicular activities, commercial activities, industrial activities, and human activities. Vehicular activities include small cars such as taxis, as well as heavy duty vehicles. Other sources of noise identified are noise from commercial activities such as service stations, shop, open markets and industrial activities of food industries and machinery fabrications. The most noise came from the horns of heavy vehicles going in and out of the adjoining street. 


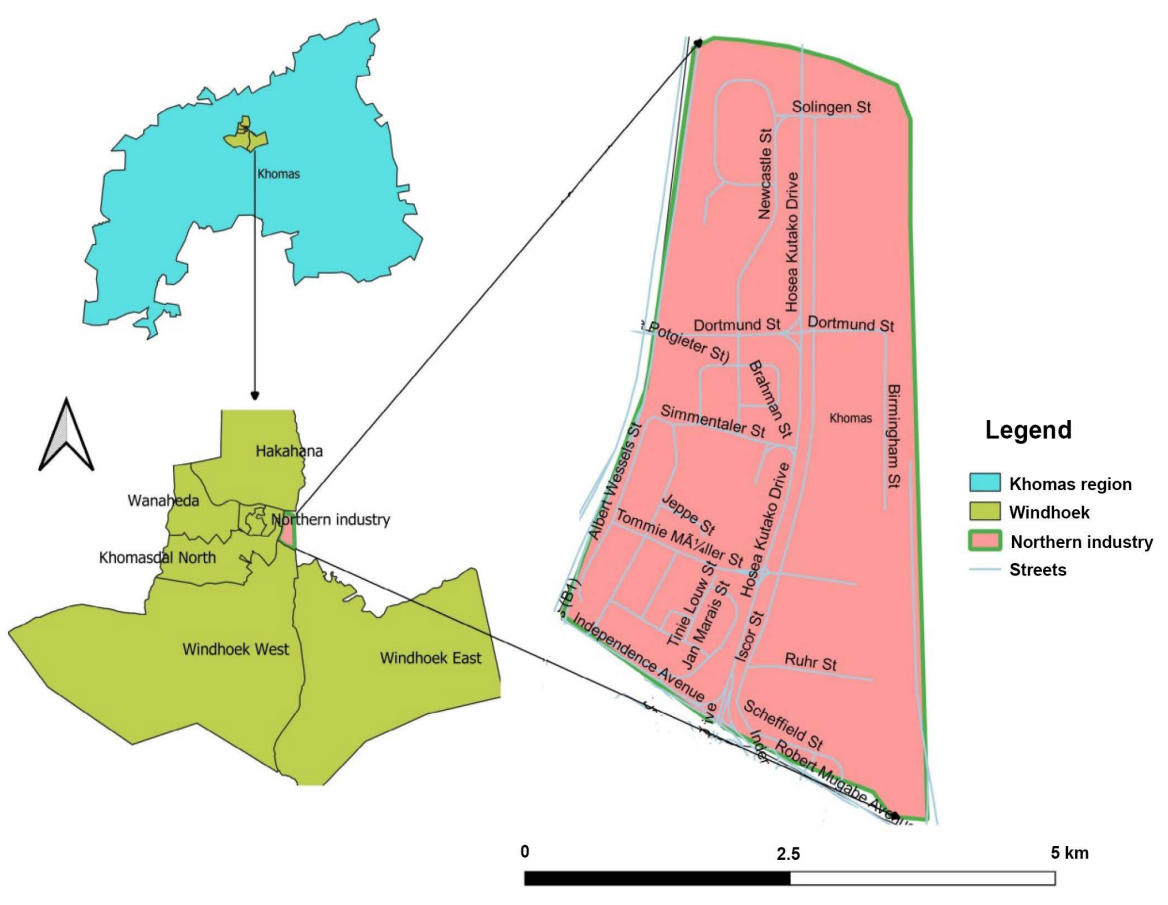

Figure 1. Map of the Northern Industrial Area, showing their respective street.

Noise pollution is less in areas where there are less vehicular movements, less shops and industries. Road traffic is one of the major sources of noise in an industrial area. The contact between tyres and road surface contribute largely to traffic noise [15]. Table 1 shows the street locations where the study was carried out, the coordinates of the locations and the different sources of noise.

\subsection{Noise Measurement}

The material used for the measurement are the 3 MTM 2200 integrating-averaging sound level meter, which contains a range of $30-140 \mathrm{~dB}$ and a weighting method of A, C, Z. stopwatch and a mobile phone. The noise pollution was measure in six streets around the northern industrial area of Windhoek. The sources of noise in each of the streets were identified and the sound level meter was used to measure the amount of noise generated from the source in decibel, at a particular distance. For the Newcastle Street, the distance of the sound level meter, from the source was within $12 \mathrm{~m}, 9 \mathrm{~m}$ for Dortmund Street, $10 \mathrm{~m}$ for Hosea Kutako Street and Simmentaler Street, then $9 \mathrm{~m}$ for Brahman Street. The time for each noise measurement were taking within an interval of 5 minutes, for a range of 2 hour that is, 8:00 - 10:00, 10:00 - 12:00, 12:00 - 14:00, and 14:00 - 16:00 hour. The measurements were taking for each street, around the industrial area during the daytime. The average noise pollution was calculated in decibel unit $\mathrm{dB}(\mathrm{A})$.

\subsection{Sound Intensity}

The measure of magnitude and direction of the flow of sound energy is known as sound intensity [16]. Sound intensity, can be measured in air, at different 
Table 1. Location, coordinates and sources of noise pollution.

\begin{tabular}{|c|c|c|c|c|}
\hline Points & Name of street & $\begin{array}{c}\text { Coordinates } \\
\text { (longitude \& latitude) }\end{array}$ & Sources of noise & $\begin{array}{c}\text { Distance from } \\
\text { source }\end{array}$ \\
\hline 1 & Bonsmara Street & $\begin{array}{l}22^{\circ} 31^{\prime} 36^{\prime \prime S} \\
17^{\circ} 4^{\prime} 31^{\prime \prime E}\end{array}$ & $\begin{array}{c}\text { Vehicular, human } \\
\text { activities, service station }\end{array}$ & Within $12 \mathrm{~m}$ \\
\hline 2 & Newcastle Street & $\begin{array}{l}22^{\circ} 31^{\prime} 28^{\prime \prime S} \\
17^{\circ} 4 ' 31^{\prime \prime} \mathrm{E}\end{array}$ & $\begin{array}{c}\text { Vehicular, human } \\
\text { activities, commercial } \\
\text { activities (shops, kapana) }\end{array}$ & Within $12 \mathrm{~m}$ \\
\hline 3 & Dortmund Street & $\begin{array}{l}22^{\circ} 31^{\prime} 36^{\prime \prime S} \\
17^{\circ} 4^{\prime} 32^{\prime \prime} \mathrm{E}\end{array}$ & Vehicular, service station & Within $9 \mathrm{~m}$ \\
\hline 4 & $\begin{array}{l}\text { Hosea Kutako } \\
\text { Drive }\end{array}$ & $\begin{array}{c}22^{\circ} 31^{\prime} 33^{\prime \prime} \mathrm{S} \\
17^{\circ} 4^{\prime} 38^{\prime \prime} \mathrm{E}\end{array}$ & $\begin{array}{c}\text { Industrial activities, } \\
\text { vehicular, human activities }\end{array}$ & Within $10 \mathrm{~m}$ \\
\hline 5 & Simmentaler Street & $\begin{array}{l}22^{\circ} 31^{\prime} 45^{\prime \prime S} \\
17^{\circ} 4{ }^{\prime} 27^{\prime \prime} \mathrm{E}\end{array}$ & $\begin{array}{c}\text { Commercial activities } \\
\text { (kapana, shop), industrial } \\
\text { activities, human activities }\end{array}$ & Within $10 \mathrm{~m}$ \\
\hline 6 & Brahman Street & $\begin{array}{l}22^{\circ} 31^{\prime} 40^{\prime \prime S} \\
17^{\circ} 4^{\prime} 26^{\prime \prime} \mathrm{E}\end{array}$ & $\begin{array}{c}\text { Industrial activities, } \\
\text { vehicular, human activities }\end{array}$ & Within $9 \mathrm{~m}$ \\
\hline
\end{tabular}

listener's location. The intensity is measured in watts $/ \mathrm{m}^{2}$ or watts $/ \mathrm{cm}^{2}$. Most of the sound intensity is measured in standard threshold of hearing intensity $I_{0}$ as shown in Equation (1) [17].

$$
l_{0}=10^{-12} \text { watts } / \mathrm{m}^{2}=10^{-16} \text { watts } / \mathrm{cm}^{2}
$$

The decibel scale is the most common approach to sound intensity measurement as presented in Equation (2).

$$
I(d B)=10 \log _{10}\left[\frac{I}{I_{0}}\right]
$$

where $I$ is the giving intensity and $I_{0}$ is the threshold of hearing intensity.

The unit of sound intensity is decibel $(\mathrm{dB})$. The sound intensity from 0 to 100 $\mathrm{dB}$ is pleasant but when the sound intensity exceeds $120 \mathrm{~dB}$, it causes noise. So, sound of more than $130 \mathrm{~dB}$ causes noise pollution. Usually $80 \mathrm{~dB}$ is the level at which sound becomes physically painful. The main threat of noise comes from transport sector in this case road traffic noise where high and faster moving vehicles produce high noise from their gear boxes, exhaust system, vibrations from their body, etc. With the increasing number of vehicles in Windhoek, road traffic noise is the most common source of noise pollution; this may be as the result of a large number of vehicle congestion during peak hours on the same road section. Therefore, we considered to be worthwhile tracking noise on a street in the central area of Northern Industrial in time slot between $08 \mathrm{~h} 00$ - $16 \mathrm{~h} 00$.

\subsection{Noise Measurement Parameter}

The prediction of noise level at the northern industrial area, were calculated using the percentile noise indices $\mathrm{L}_{10}, \mathrm{~L}_{50}$, and $\mathrm{L}_{90}$. The $10 \%$ of measuring period is represented by $L_{10}$, while $L_{50}$ and $L_{90}$ represent the $50 \%$ and $90 \%$ of measuring period. The respective percentile noise level indices were evaluated from Equa- 
tions (3)-(6) [18] [19] [20].

$$
\begin{gathered}
L_{e q}=L_{10}+0.018\left(L_{10}-L_{90}\right)^{2} \\
L_{10}=61+8.4 \log (Q)+0.15 P-11.5 \log (d) \\
L_{50}=44.8+10.8 \log (Q)+0.12 P-9.6 \log (d) \\
L_{90}=39.1+10.5 \log (Q)+0.06 P-9.3 \log (d)
\end{gathered}
$$

where $Q$ is the total vehicle, $P$ is the percentages of heavy vehicle and $d$ is the distance from the source of noise to the receivers.

There are periods were the sound level recorded by the sound level metre are fluctuating with respect to time. This may be because of the direction of wind from the source, or road traffic vehicular noise moving far away or closer to the measurement metre and other causes of noise that is generating an unstable sound. The Noise Climate ( $N C$ ) formula in Equation (7) below is used to determine the range over which the noise level is changing [18].

$$
N C=L_{10}-L_{90}
$$

Another noise index of importance in characterizing noise pollution is the traffic noise index. The traffic noise index is a parameter that determines the degree of change in the traffic flow in an area [18]. The traffic noise index was calculated using Equation (8).

$$
T N I=4\left(L_{10}-L_{90}\right)+\left(L_{90}-30\right)
$$

\section{Result and Discussion}

The noise pollutions measured for each of the streets around the industrial area of Windhoek, Namibia, are shown in Table 2.

The respective recommended limit for noise exposure during the daytime is $70 \mathrm{~dB}$ (A) [21]. Table 2 shows the average noise pollution recorded by the sound level meter between a time intervals of 8:00 am - 16:00 pm. It is clearly seen from the table, that the maximum level of noise pollution obtained from our study is higher than those recommended by WHO and the National Environmental Noise Regulation standard of $70 \mathrm{~dB}$ (A). However, our results are lower than

Table 2. Average Noise Level $\mathrm{dB}$ (A) recorded at time interval from the different locations, in the Northern Industrial Area.

\begin{tabular}{ccccc}
\hline Street names & \multicolumn{4}{c}{ Average Noise Level dB (A) } \\
\hline & $\begin{array}{c}8: 00 \mathrm{am}- \\
10: 00 \mathrm{am}\end{array}$ & $\begin{array}{c}10: 00 \mathrm{am}- \\
12: 00 \mathrm{pm}\end{array}$ & $\begin{array}{c}12: 00 \mathrm{pm}- \\
14: 00 \mathrm{pm}\end{array}$ & $14: 00 \mathrm{pm}-$ \\
\hline Bonsmara Street & 72.5 & 71.5 & 64.4 & 67.5 \\
Newcastle Street & 67.4 & 67.9 & 75.3 & 68.8 \\
Dortmund Street & 81.0 & 60.5 & 72.6 & 72.7 \\
Hosea kutako Drive & 63.3 & 66.9 & 62.5 & 72.3 \\
Simmentaler Street & 72.3 & 82.3 & 66.0 & 70.1 \\
Brahman Street & 65.1 & 66.7 & 76.8 & 69.5 \\
\hline
\end{tabular}


those reported by Edgar et al. in Columbia, which have "79.7 dB (A) during business day and $77.7 \mathrm{~dB}(\mathrm{~A})$ during non-business day" [22] and compared favorably with the study reported in Iran, which is "70 dB (A) in $80 \%$ of the sites during weekdays" [23].

Tables 3-6 show the variation of noise level index $\mathrm{L}_{10}, \mathrm{~L}_{50}, \mathrm{~L}_{90}$ and $\mathrm{L}_{\text {eq }}$ calculated from the noise level, measured in $\mathrm{dB}(\mathrm{A})$, at the various streets (Bonsmara, New Castle, Brahman, Hosea Kutako, Simmentaler and Dortmund), around the Northern Industrial Area. The mean values of noise level index $\mathrm{L}_{10}, \mathrm{~L}_{50}, \mathrm{~L}_{90}$ obtained from our study are shown on the Tables 3-6. The mean noise level index $\mathrm{L}_{10}$, obtained from all the streets are above the WHO recommended limit of 70 $\mathrm{dB}(\mathrm{A})$, except that of New Castle Street, which is slightly below the recommended limit. However, the mean value of noise level index $\mathrm{L}_{50}$ and $\mathrm{L}_{90}$ obtained from the all the streets were below WHO recommended limit of $70 \mathrm{~dB}$ (A) [21].

The Noise Climate (NC) and Traffic Noise index (TNI) were calculated, as shown in Figure 2 and Figure 3 respectively. The mean Noise Climate and the Traffic Noise index (TNI) variation obtained from Bonsmara, New Castle, Brahman, Hosea Kutako, Simmentaler and Dortmund Street at a time interval of 08:00 am - 16:00 pm, were shown clearly on the figures. The noise climate variation in the entire street, have a close range to each other, except that of Hosea Kutako Street, which is a bit higher than the other with a value of $17.7 \mathrm{~dB}(\mathrm{~A})$. The values of traffic noise index recorded in the entire street were higher than the traffic noise recommended limit of $53(\mathrm{~dB})$ recommended by WHO [21].

\section{Conclusions}

There exist a lot of proximate residential buildings and major industries along the streets of the northern industrial areas of Windhoek. Workers and residents can be affected by a large amount of sound pressure generated from different sources with attendant risk from noise pollution. From the study, it was observed that several sampling points recorded high average noise levels above WHO recommended limit. This implies that the more time industrial workers

Table 3. Noise level $\left(\mathrm{L}_{10}\right)$ variation at different street locations, in the Northern Industrial Area.

\begin{tabular}{ccccccc}
\hline \multirow{2}{*}{ Time interval } & \multicolumn{5}{c}{ Street names at Northern Industrial Area } \\
\cline { 2 - 7 } & Bonsmera & New Castle & Brahman & Hasea-Kutako & Simmentaler & Dortmund \\
\hline 08:00 - 10:00 & 73.5 & 68.6 & 70.0 & 74.9 & 72.8 & 75.1 \\
10:00 - 12:00 & 72.4 & 70.1 & 67.5 & 80.7 & 71.8 & 72.6 \\
12:00 - 14:00 & 72.0 & 70.5 & 66.2 & 79.4 & 72.9 & 73.0 \\
14:00 - 16:00 & 73.1 & 70.0 & 65.0 & 75.8 & 71.4 & 74.0 \\
Mean & 72.8 & 69.8 & 67.2 & 77.7 & 72.2 & 73.7 \\
Min & 72.0 & 68.6 & 65.0 & 74.9 & 71.4 & 72.6 \\
Max & 73.5 & 70.5 & 70.0 & 80.7 & 72.9 & 75.1 \\
\hline
\end{tabular}


Table 4. Noise level $\left(\mathrm{L}_{50}\right)$ variation at different street locations, in the Northern Industrial Area.

\begin{tabular}{ccccccc}
\hline \multirow{2}{*}{ Time interval } & \multicolumn{5}{c}{ Street names at Northern Industrial Area } \\
\cline { 2 - 7 } & Bonsmara & New Castle & Brahman & Hosea-Kutako & Simmentaler & Dortmund \\
\hline 08:00 - 10:00 & 64.8 & 59.6 & 60.8 & 66.6 & 64.9 & 67.2 \\
10:00 - 12:00 & 63.6 & 61.3 & 58.1 & 69.9 & 63.3 & 63.8 \\
12:00 - 14:00 & 63.9 & 62.4 & 56.4 & 70.5 & 64.6 & 64.7 \\
14:00 - 16:00 & 63.7 & 61.7 & 54.8 & 67.3 & 63.2 & 65.3 \\
Mean & 64.0 & 61.3 & 57.5 & 68.6 & 64.0 & 65.3 \\
Min & 63.6 & 59.6 & 54.8 & 66.6 & 63.2 & 63.8 \\
Max & 64.8 & 62.4 & 60.8 & 70.5 & 64.9 & 67.2 \\
\hline
\end{tabular}

Table 5. Noise level $\left(\mathrm{L}_{90}\right)$ variation at different street locations, in the Northern Industrial Area.

\begin{tabular}{|c|c|c|c|c|c|c|}
\hline \multirow{2}{*}{ Time interval } & \multicolumn{6}{|c|}{ Street names at Northern Industrial Area } \\
\hline & Bonsmara & New Castle & Brahman & Hosea- Kutako & Simmentaler & Dortmund \\
\hline 08:00 - 10:00 & 57.3 & 53.2 & 54.3 & 59.5 & 58.6 & 60.4 \\
\hline $10: 00-12: 00$ & 56.3 & 54.7 & 52.1 & 59.3 & 56.7 & 57.0 \\
\hline $12: 00-14: 00$ & 57.1 & 56.1 & 50.4 & 61.6 & 57.9 & 58.1 \\
\hline $14: 00-16: 00$ & 55.9 & 55.3 & 48.9 & 59.8 & 56.8 & 58.1 \\
\hline Mean & 56.7 & 54.8 & 51.4 & 60.1 & 57.5 & 58.4 \\
\hline Min & 55.9 & 53.2 & 48.9 & 59.3 & 56.7 & 57.0 \\
\hline Max & 57.3 & 56.1 & 54.3 & 61.6 & 58.6 & 60.4 \\
\hline
\end{tabular}

Table 6. The noise level equivalent $\left(\mathrm{L}_{\mathrm{eq}}\right)$ variation at different street locations, in the Norther Industrial Area.

\begin{tabular}{ccccccc}
\hline \multirow{5}{*}{ Time interval } & \multicolumn{5}{c}{ Street names at Northern Industrial Area } \\
\cline { 2 - 6 } & Bonsmara & New Castle & Brahman & Hosea-Kutako & Simmentaler & Dortmund \\
\hline 08:00 - 10:00 & 78.2 & 72.9 & 74.4 & 79.2 & 76.4 & 79.0 \\
10:00 - 12:00 & 77.1 & 74.4 & 71.8 & 88.9 & 75.9 & 77.0 \\
12:00 - 14:00 & 76.0 & 74.2 & 70.7 & 85.1 & 77.0 & 77.0 \\
14:00 - 16:00 & 78.4 & 73.9 & 69.7 & 80.4 & 75.2 & 78.6 \\
Mean & 77.4 & 73.9 & 71.7 & 83.4 & 76.1 & 77.9 \\
Min & 76.0 & 72.9 & 69.7 & 79.2 & 75.2 & 77.0 \\
Max & 78.4 & 74.4 & 74.4 & 88.9 & 77.0 & 79.0
\end{tabular}




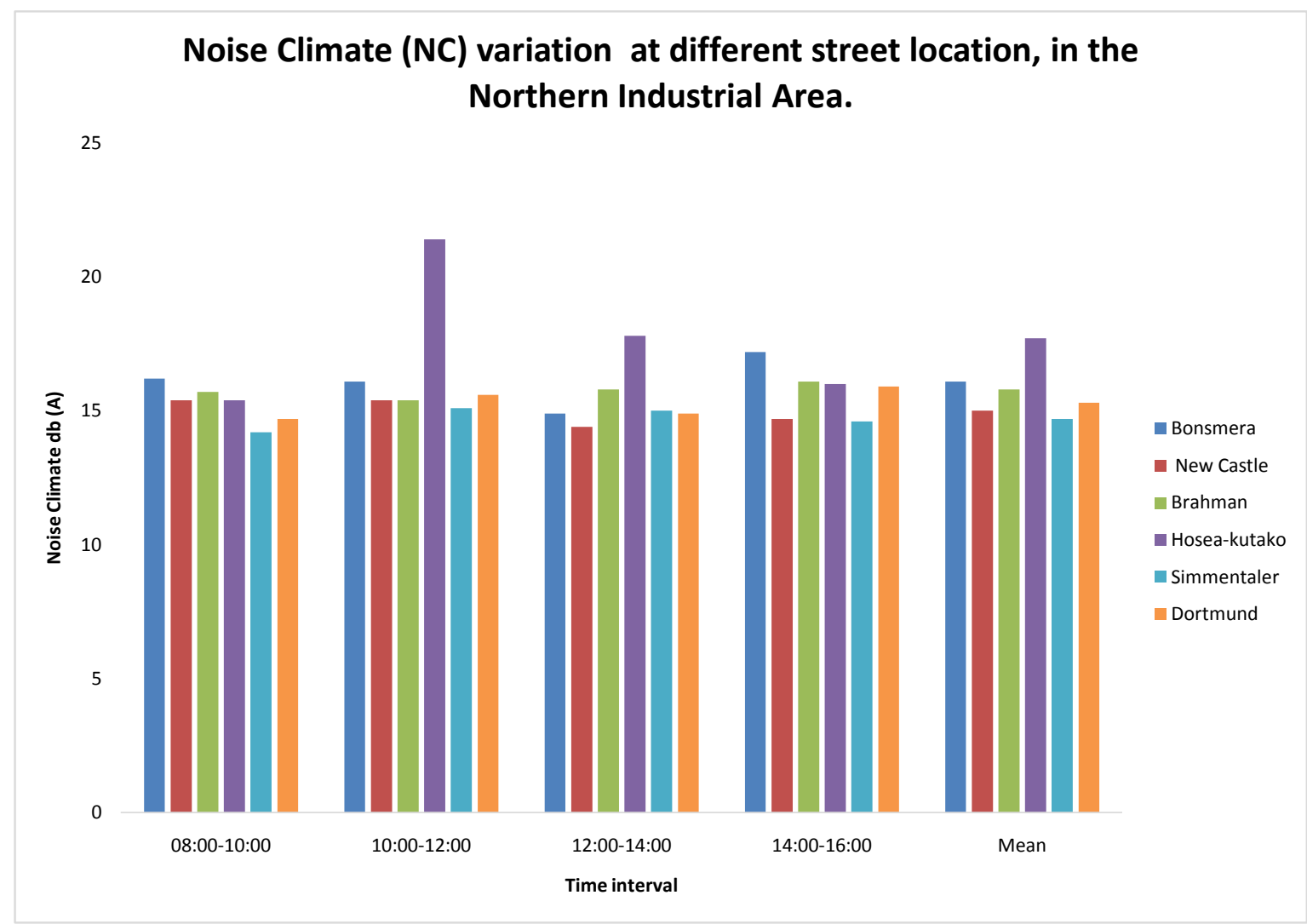

Figure 2. Noise Climate (NC) variation at different street locations, in the Northern Industrial Area.

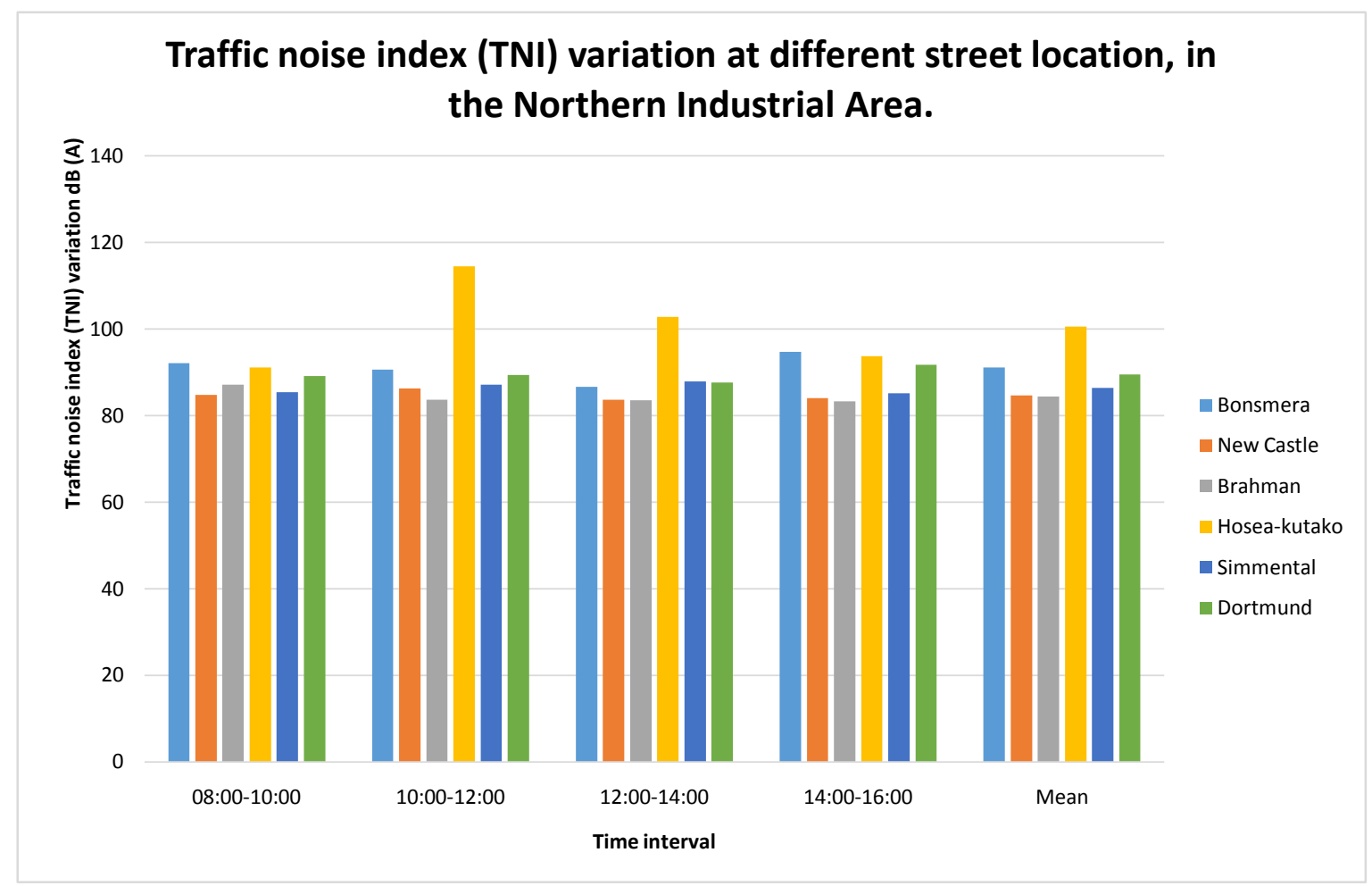

Figure 3. Traffic Noise Index (TNI) variation at different street locations, in the Northern Industrial Area. 
and residents spent in those areas during the period of this analysis, the more they are likely to be exposed to environmental noise hazards. This noise pollution may have an accumulative effect on their health which may lead to diseases that may result in continuous health deterioration. The noise level percentile indices $\mathrm{L}_{10}, \mathrm{~L}_{50}, \mathrm{~L}_{90}$ and $\mathrm{L}_{\mathrm{eq}}$ were determined. The results showed some percentile indices below the WHO recommended limit. The major sources of noise that contribute to the noise pollution as identified in the study are from the road traffic noise. Therefore, we recommend measures be put in place to minimize the levels of road traffic noise from the north industrial area of Windhoek City, Namibia.

We suggest that monitoring should be replicated at the southern industrial area of Windhoek Namibia, to form a baseline for noise level around the industrial establishment in the capital city.

\section{Acknowledgements}

We sincerely appreciate Namibia University of Science and Technology for assisting us with 3MTM 2200 integrating-averaging sound level meter and other equipment we used, in carrying out the study.

\section{Conflicts of Interest}

The authors declare no conflicts of interest regarding the publication of this paper.

\section{References}

[1] Greicikely, G.P., Cristina, E.A. and Paulo, H.T.Z. (2017) Relationship between Urban Noise and the Health of Users of Public Spaces-A Case Study in Vitoria, ES. Brazil Journal of Building Construction and Planning Research, 5, 45-57. https://doi.org/10.4236/jbcpr.2017.52004

[2] Arline, L.B. (2017) Impact of Noise on Health: The Divide between Policy and Science. Open Journal of Social Sciences, 5, 108-120.

https://doi.org/10.4236/jss.2017.55008

[3] Enock, A.W. and Galcano, C.M. (2015) Noise Pollution Mapping Using GIS in Nairobi, Kenya. Journal of Geographic Information System, 7, 486-493. https://doi.org/10.4236/jgis.2015.75039

[4] Abbas, M., Pezhman, H. and Maede, G. (2017) Comparison of Mental Health Status of People Exposed to Noise Pollution with People in Non-Polluted Areas of Sari. Health, 9, 839-848. https://doi.org/10.4236/health.2017.95059

[5] Rajiv, B.H. and Yogesh, B.P. (2012) Assessment of Noise Pollution Indices in the City of Kothapur India. Procedia-Social and Behavioral Sciences, 37, 448-457. https://doi.org/10.1016/j.sbspro.2012.03.310

[6] Madbuli, H.N, Abdullah, O.B and Ibrahim, M.J. (2014) Noise Pollution in Metalwork and Woodwork Industries in the Kingdom of Saudi Arabia. International Journal of Occupational Safety and Ergonomics, 20, 661-670. https://doi.org/10.1080/10803548.2014.11077068

[7] Balashanmugam, P., Ramanathan, A.R., Nehrukumar, V. and Balasubramaniyan, K. (2013) Assessment of Noise Pollution in Childambaram Town. International Journal of Research in Engineering and Technology, 2, 85-93. 
[8] Jibran, K., Matthias, K., Konstantinos, K., Mette, S. and Steen, S.J. (2018) Road Traffic Air and Noise Pollution Exposure Assessment-A Review of Tools and Techniques. Journal of Science of the Total Environment, 634, 661-676. https://doi.org/10.1016/j.scitotenv.2018.03.374

[9] Nathalie, A., Mathilde, D., Marianne, B.B., Ernest, L. and Audrey, S. (2018) Environment Noise Pollution and Risk of Preeclampsia. Journal of Environmental Pollution, 239, 599-606. https://doi.org/10.1016/j.envpol.2018.04.060

[10] Balashanmugam, P., Nehrukumar, V., Balasubramaniyan, K. and Balasubramanian, G. (2013) Effect of Road Traffic Noise Pollution in Cuddalore Town: A Case Study. International Journal of Innovative Research in Science, Engineering and Technology, 2, 5741-5751.

[11] Obot, O.W. and Ibanga, S.M. (2014) The Impact of Noise Pollution on Productivity: A Case Study of University of Uyo, Nigeria. Indian Journal of Computer Science and Engineering, 5, 9-14.

[12] Beta, B.S., Susilo, I. and Eddy, Y. (2017) Noise Evaluation of Traffic flows and Its Effect to Concentration Capability of the Student in One of Private School in Surabaya. Procedia Engineering, 170, 274-279.

https://doi.org/10.1016/j.proeng.2017.03.026

[13] Serkan, O., Murat, Z. and Hasan, Y. (2014) Determination of the Noise Pollution on University (Education) Campuses: A Case Study of Ataturk University. Ekoloji, 23, 49-54. https://doi.org/10.5053/ekoloji.2014.906

[14] http://en.Wikipedia.org/wiki/Windhoek

[15] Narendra, S. and Davar, S.C. (2004) Noise Pollution-Sources, Effect and Control. Journal of Human Ecology, 16, 181-187. https://doi.org/10.1080/09709274.2004.11905735

[16] Croker, M.J. and Arenas J.P (2003) Fundamentals of the Direct Measurement of Sound Intensity and Practical Applications. Journal of Acoustical Physics, 49, 163-175. https://doi.org/10.1134/1.1560378

[17] Michael, S. (2009) Determination of Sound Power Levels Using Sound Intensity. Vaasan Ammattikorkeakoulu University of Applied Science, Vaasa, 89.

[18] Bijay, K.S. and Shreerup, G. (2013) Integrating and Comparison of Assessment and Modeling of Road Traffic Noise in Baripada Town, India. International Journal of Energy and Environment, 4, 303-310.

[19] Nwobi, O.C.C., Uyaelumuo, A.E., Okoronkwo, G.O and Duru, C.A. (2015) Analysis and Modelling of Road Traffic Noise in Onitsha Metropolis, Nigeria. International Journal of Advance Multidisciplinary Research Reports, 1, 1-20.

[20] Quartieri, J., Nikos, M., Gerardo, I., Claudio, G., Ambrosio, S.D., TroIsi, A. and Lenza, T.L.L. (2014) A Review of Traffic Noise Prediction Models. Recent Advances in Applied and Theoretical Mechanics, 3, 72-80.

[21] WHO (2018) Environmental Noise Guidelines for the European Region. WHO Regional Office for Europe UN City, Denmark, 19-21.

[22] Edgar, E.Q.B., Ciro, F.B.L. and Mehrab, M. (2016) A Traffic Noise Model for Road Intersections in the City of Cartagena de Indias, Colombia. Transportation Research Part D, 47, 149-161. https://doi.org/10.1016/j.trd.2016.05.007

[23] Peyman, H.M., Ali, A.F., Roksana, M. and Rouhangiz, J.O. (2015) Assessment of the Living and Workplace Health and Safety Conditions of Site-Resident Construction Workers in Tehran, Iran. International Journal of Occupation Safety and Ergonomics, 21, 568-573. https://doi.org/10.1080/10803548.2015.1096061 